\title{
The 1926 Annexation of Southern Kurdistan to Iraq: the Kurdish Narrative
}

\author{
Aram Rafaat \\ aramrafaat07@yahoo.com
}

Received Date: May 31, 2017

Accepted Date: June 12, 2017

Published Date: June 27, 2017

Abstract: The collapse of the Ottoman Empire and the establishment of many 'nation-states' in the region, alongwith promises given to the Kurds following World War I, had revived Kurdish hopes for the establishment of their own independent state. Initially, Britain made a clear-cut political and administrative distinction between Southern Kurdistan and Iraq and reluctantly supported a local Kurdish government. By 1924, however, the British had destroyed the Kurdish government and one year later, through the League of Nations, arranged a referendum to provide a legitimate framework for the attachment of Kurdistan to Iraq. From the very beginning, Kurdish leaders rejected the legitimacy of Iraqi rule in Kurdistan by insisting on their right to self-determination and the establishment of an independent Kurdish state. This perspective has been shared by all successive generations of Kurdish nationalists until the present day. Accordingly, the Iraqi-Kurdish conflict has plagued the country since the 1920s with the incorporation of the Kurdish region into the newly created nation state of Iraq.

Keywords: Kurds, Kurdish Nationalism, Britain, League of Nations, Iraq

\section{INTRODUCTION}

This article is relevant to the debates taking place today, regarding the nature of the Iraqi Kurdish conflict and thefuture of the state of Iraq. It investigates crucial and less explored questions related to the Kurds' perspective on the process of annexation of the Kurdish region to Iraq in the 1920s. In an effort to address the problem, many scholars on Kurdish issueshave dealtwith good governance policies, political space and democratisation, and the federalism of Iraq. However,little attention, if any, has been given to the question of how the Kurds perspective on the creation of Iraq and the manner in which the Kurdish region was attached to itin the 1920s havereshaped Kurdish-Iraqi relations. Additionally, very few scholarswho focused on the Kurdish-Iraqi conflict were able to have access to resources andbooks written in Kurdish and Arabic. Consequently, literature on Kurdish study failed forthe most part, to include the Kurdish perspective on the process of annexation of their region to Iraq after World War I (WWI).This article presents the Kurdish narrative in their voice and by using previously untapped Kurdish and Arabic resources. It explains why a Kurdish narrative helps in the understandingof the nature of Kurdish nationalism and the Iraqi-Kurdish conflict.

Initially, the article briefly highlights the manner in which Southern Kurdistan was incorporated into Iraq. ${ }^{1}$ Then it investigates how the international communities, the League of Nations and the British colonial power dealt with the Kurdish issues prior to the incorporation of Southern Kurdistan within Iraq. It highlights promises that were given to the Kurds by international actors and how these promises reshaped their hopes and expectations to attain independence. Next, it tackles the question of how and why the Kurds rejected the legitimacy of the attachment process and, accordingly, Iraqi rule in the Kurdish region. This article attempts to cover the narrative of successive generations of Kurdish nationalists. Chronologically Kurdish nationalists can be divided onto four generations: the first generation (1918 to 1938), the second generation (1939-1960), the third generation (1961-1990), and the most recent generation (1991-present). 
The focus will be on narratives of these generations on three intertwined topics. Firstly, the article tackles the question of how the Kurds perceived the referendum held by the League of Nations to determine the future of Southern Kurdistan. Secondly, it addresses the question of how the Kurdish nationalists perceived the role of Great Britain in the process of annexation of their land to Iraq. Finally, the article attempts to answer the question of whether the Kurds rejection of the legitimacy of the annexation process means their denial of the legitimacy of Iraqi authority in Kurdistan. This study also traces the relationship between the process of annexation of Southern Kurdistan to Iraq and the Kurds demand for the right of self-determination. By doing so, this article explains how and to what extent the Kurds' perspective on the incorporation of Southern Kurdistan into Iraq has become the main obstacle to their integration within Iraq, and therefore the basis of the Iraqi-Kurdish conflict.

\section{From Hope of IndePENDENCE TO A NEGLECTED MinORITY}

The modern state of Iraq was created in 1921, initially out of two Ottoman provinces, Basra and Baghdad. These two provinces were occupied by Britain in 1914 and 1917 respectively. On November 2, 1918, Britain also invaded Mosul city, the capital of another Ottoman province, namely the province of Mosul. This province constituted the major area of what is today known as Iraqi Kurdistan. In addition to the city of Mosul,the colonial power invaded the city of Kirkuk and the rest of the Kurdish region of Southern Kurdistan mostly remained outside its rule or only had a symbolic presence. ${ }^{2}$ In fact, the rest of Southern Kurdistan was controlled through its Royal Air Forces (RAF). In 1926, however, Southern Kurdistan was officially attached to the newly created state of Iraq.

Prior to the League of Nations' recommendations, Kurdish right to self-rule and even to an independent state had been emphasised by several international treaties and declarations. The US President Woodrow Wilson's famous Fourteen Points, declared on January 8, 1918, is a prime example. President Wilson not only promoted the principles of self-determination, but he also aided and abetted the Kurdish hopes to attain such a right. In Point 12, Wilson declared that "other nationalities which are now under Turkish rule should be assured an undoubted security of life and an absolutely unmolested opportunity of autonomous development." ${ }^{3}$ Thus, seeing them as one of the non-Turkish minorities of the Ottoman Empire, Wilson promised self-determination for the Kurds. The Paris (Versailles) Peace Conference held in 1919, an international conference in which a Kurdish delegation was represented, produced another international document. In a memorandum to the Conference, Sharif Pasha, the head of the Kurdish delegation, presented a map of 'greater Kurdistan' for the proposed independent Kurdish state. ${ }^{4}$ The Conference went on to support the principle of self-determination for the Kurds. Another international document is Articles 61 and 63 of the Treaty of Sevres (1920) which clearly proposed an independent Kurdish state. ${ }^{5}$ The commonly held belief among the Kurds was that their right to self-determination had been recognised in several treaties and, as a result, they were entitled to practice such self-determination. Thus, the Kurds' hope to attain autonomy and independence had been formally substantiated.

From 1918 to 1924, that is prior to the formal annexation of Southern Kurdistan to Iraq, Britain dealt with the Kurdish region as a separate entity. In this period, the Kurds enjoyed a degree of self-rule, albeit intermittently. While the British occupied Iraq and imposed direct colonial rule in Iraq for several years (with the exception of Kirkuk), Kurdistan had never experienced this. In fact, the British made a clear-cut political and administrative distinction between Southern Kurdistan and Iraq. ${ }^{6}$ They proposed an autonomous Kurdistan region and even recognised the authority of Sheikh Mahmud as a Hukmdar(Ruler). ${ }^{7}$ Sheikh Mahmud founded his first government in October 1918 which lasted until June 1919. This nascent Kurdish sta te raised the Kurdistan flag, designed its emblem and issued stamps to represent it. ${ }^{8}$ In November 1918, Sheikh Mahmud replaced the Turkish language with Kurdish as the official language of Kurdistan. ${ }^{9}$ On June 9, 1919, however, Sheikh Mahmud was captured by the British forces and was taken to Baghdad for trial. ${ }^{10} \mathrm{He}$ was charged by the British with armed rebellion, bringing down the British flag and raising the Kurdistan flag. The court sentenced him 
to death, but the sentence was commuted to ten years' imprisonment and he was sent to the Andaman Islands in India to serve out his sentence. ${ }^{11}$ Under pressure from the Kurdish people, Britain finally released Sheikh Mahmud and permitted him to return from exile in 1922. With the help of British officials he established the second Kurdish government that lasted until 1924, and proclaimed himself as the King of Kurdistan. During this period, the role of British officials in Kurdistan was confined to that of providing political and administrative advice to Sheikh Mahmud. British officials in London and the Middle East often referred to the autonomous entity as the 'Kurdish state.'

Despite this, neither the international treaties were implemented, nor did British support for the Kurdish autonomy continue. The international communities' promises have never come to fruition; the Kurds were left without a state as they became a minority in the newly created state of Iraq, Iran, Turkey and Syria. The Treaty of Lausanne between Turkey and the victorious Allies in 1923, which superseded the Treaty of Sèvres, bore no specific reference to the Kurds; instead it promised only tolerance for minorities in general. As we have seen above, from 1918 to 1923, British policy fluctuated with regard to Kurdish independence. However, by 1924, the British had abandoned its policy of supporting a Kurdish autonomy and/or independence. Instead, the British placed demands on Kurdistan on behalf of Iraqand used their position as a mandate and colonial power to incorporate the region into Iraq. Britain also used different means to eliminate the Kurdish national movement. With massive bombings the British terrorised the Kurdish populace, destroyed the Kurdish government of Sheikh Mahmud, and occupied its capital in $1924 .{ }^{12}$ To accomplish their mission, and to provide a legitimate framework for this process of annexation, Britan mandated the League of Nations to hold a symbolic referendum over the future of Mosul provice (i.e. Southern Kurdistan). The British were already involved in a dispute with Turkey, and were also fighting with the Kurds over the future of Kurdistan. Within this environment it was expected that the League of Nations' recommendation would more closely reflect British interests rather the Kurdish desires.

To arrange the referendum and determine the future of the Kurdish region, the League of Nations established a Fact-Finding Commission (FFC) in September 1924. A referendum was held by the FFC in 1925, the main question being whether the people of Mosul province (Kurdistan) wanted to be part of Iraq or Turkey. Following the referendum, the League of Nations recommended the incorporation of Mosul province into the Iraqi state. In its report the FFC revealed that if the ethnic consideration had to be taken into account, an independent state of Kurdistan should be established. As the FFC admitted most of the people of Kurdistan did not possess any feeling of solidarity with the Arab kingdom of Iraq. ${ }^{13}$ The lack of popularity for the idea of annexing Kurdistan to Iraq is evident in that only 32 out of 6,000 people in Sulaimaniyah city voted for Iraq. ${ }^{14}$ Moreover, the FFC ruled out the option of an independent Kurdish state and only offered the choice of a union with Turkey or Iraq. ${ }^{15}$ Since the FFC referendum was limited to tribal chiefs, sheikhs and religious notables, the majority of the population was excluded. Many of those who did participate were not aware of the goal behind the referendum and its political consequences; in addition, they were not offered other alternatives. ${ }^{16}$ In sum, by 1924 , Great Britain destroyed the Kurdish self-rule and by 1925, the nascent Kurdish hopes for autonomy or independence were squashed. One year later, in 1926, Southern Kurdistan was officially attached to the newly created state of Iraq. Thus, the Kurds were left without a state as they became a neglected minority in the Arab dominated state of Iraq.

\section{THE KuRds' Rejection of THE LEAGUE'S DeCision}

The manner in which the Kurdish region was attached to Iraq had a profound effect on Kurdish nationalism and Kurdish-Iraqi relations. Scrutiny of the political discourse and literature of four different generations of Kurdish nationalism explains how the Kurds perceived the League of Nations' decision. The first generation is those who fought for an independent Kurdistan against Britain and later the Iraqi state after the annexation of Kurdistan to Iraq. Sheikh Mahmud, who established a de facto Kurdish self-rule from 1918-1920 and 1922-1924 and later 
fought for Kurdish independence until 1932, is a striking example. He rejected the legitimacy of the League of Nations' decision to authorise Britain to force Kurdistan to join Iraq. In a letter to the League he stated that their decision was a grave injustice that harmed the moral status and reputation of the League. ${ }^{17}$ The importance of Sheikh Mahmud's stance lies in the fact that he was and still is considered by many Kurds as a king of the first Kurdish kingdom in the modern era. Another example of the perceptions of this generation is the nationalist poet Sheikh Salam, who witnessed the rise and decline of Sheikh Mahmud's rule. He described the League as a wily and deceptive organisation that had become a stick in the hands of the British. ${ }^{18}$

The second generation is the post WWII Kurdish nationalistswho created modern political organisations and introduced modern ideologies such as democracy, leftism, and liberalism into Kurdish society. This generation of Kurdish nationalists built their discourse on the illegitimacy of the process of annexation and the Iraqi rule of Kurdistan. For example, in its proclamation, dated 18th January 1946, the Kurdish RizgariParty, ${ }^{19}$ described the process of annexation of Kurdistan to Iraq as a division of "Kurdistan by force and without consulting the Kurds." ${ }^{20}$ The Kurdistan Democratic Party (KDP), a party that has dominated the Kurdish political sphere since its establishment in 1946, is another example. In its National Charter, ratified in 1946, the KDP charged the League with disregarding the Kurdish voice for the realisation of their liberty and dealing with Kurdistan as war booty. Viewing in this way, the KDP described the League asan agency of the imperialist countries that safeguarded British interests. ${ }^{21}$

The third generation of the Kurdish nationalist movement, who lead the military rebellion against the state of Iraq, followed the same norms of their predecessors in rejecting the legitimacy of the annexation process. For example, in 1970, Jalal Talabani, then the leader of the politburo faction of the KDP,stressed the illegitimacy of the annexation of Kurdistan to Iraq and considered it as a decision imposed by the British. ${ }^{22}$ Nawsherwan M. Emina nationalist leader, the second in charge of the Patriotic Union of Kurdistan (PUK) and the secretary general of the Kurdistan Toilers' League (Komalla), is another example. ${ }^{23} \mathrm{He}$ maintained that the League of Nations was a protector of British interests and Kurdistan was attached to Iraq based on British interests and requests. ${ }^{24}$ The fourth generation of the Kurdish nationalist movement represents the post-1991 uprising which led to the establishment of a de facto Kurdish state known as the Kurdistan Region. This generation also joined their predecessors in rejecting the legitimacy of the League's decision and considering Iraq as an occupier of Kurdistan. For instance, The New and Modern History, a history curriculum for grade 12 high school students in the Kurdistan region, teaches that the Kurds' desire was for an independent state, but the League of Nations decided to annex Kurdistan to Iraq without consulting its population. ${ }^{25}$ The textbook also describes Kurdistan as an "occupied country" and the Kurds as "a subjugated nation." ${ }^{26}$ Thus, the common belief among successive generations of Kurdish nationalists since the annexation of Southern Kurdistan to Iraq is that of the League of Nations' decision was illegitimate and did not represent the desire of the Kurdish population.

\section{AtTACHing Kurdistan to IraQ: A DeCision Imposed by THE BRITISH}

All successive generations of Kurdish nationalists described above also share a similar on the role of the British in incorporating Southern Kurdistan into Iraq by means of force. Being part of Iraq, from Kurds perspective, was an imposition designed to fulfil the goals and intentions of British colonialism rather of the Kurds. The first generation of Kurdish nationalists resented their new status as minorities in Iraq. Their hope for independence was undermined, the administrative autonomy promised to the Kurds was abandoned, and their cultural and linguistic rights were compromised. In addition to these disappointments, the King and the Iraqi state elite advocated centralism and pan-Arabism. This resulted in creating new wounds and deepening existing ones. Kurdish nationalist feelings were further heightened as a result. Highlighting Britain's role in the process of annexation of Southern Kurdistan to Iraq, Sheikh Mahmud stated that only with the help of the British army and the Royal Air Force (RAF) could Iraqi Arab forces enter Kurdistan. ${ }^{27}$ Rightly or wrongly, Sheikh Mahmud believed that were it not for the British support offered to the Iraqi state, not only the liberation of Kurdistan 
from Arab rule but the occupation of Baghdad by the Kurds would have been possible ${ }^{28}$ Similarly, Sheikh Kadir, a Kurdish nationalist who acted as the Prime Minister in Sheikh Mahmud's government, stressed that only the presence of the British enabled the Arabs to enter Kurdish territory. ${ }^{29}$

The Anglo-Iraqi Treaty of 1930 terminated the British mandate and guaranteed the independence of Iraq and its membership in the League by $1932 .{ }^{30}$ The Kurds were both shocked and disappointed by the manner in which the British mandate was terminated and Iraq's subsequent independence granted. This strategic plan was implemented without obliging Iraq to fulfil promises already made to the Kurds. The Kurds accused the League of Nations, the British, and Iraq of failing to fulfil their commitment to the Kurds, by engaging in actions that were interpreted to be a wholesale betrayal of their express commitment to the Kurds. ${ }^{31}$ The feeling of being betrayed further alienated the Kurds and their oppositional status was augmented to the extent that their inherent rivalry developed into a military confrontation that would last for decades. A supreme irony is that the same Kurdish rebels that fought the British and Iraqis also sought British protection. Sheikh Mahmud and Mustafa Barzani, who were in constant rebellion against the British, preferred British rule over that of the Iraqis. In two separate memoranda, both leaders demonstrated their willingness to obey the British rather than the Iraqis. ${ }^{32}$ Viewing Iraq as an occupier of Kurdistan, the Kurds insisted on League of Nations' protection from the exploitation of Iraq. ${ }^{33}$ From 1930 to 1932, Kurdish leaders and different segments of Kurdish society presented dozens of petitions to the League and often to the British seeking support. Kurdish demands ranged from a limited autonomy to the independence of Kurdistan.

In 1930, the year of the Anglo-Iraqi Treaty, three Kurdish political organizations were founded. The first was the clandestine National Committee, and the second was the licensed Victory Association. The latter was founded as a cultural association, but soon was banned due to its political activities aimed against the British-Iraqi rulers. The third was the Kurdish Progressive Association that centered its political activities on reverse the British decision of the attachment of Kurdistan to Iraq. During the second half of 1930, two new organisations were founded that demonstrated a more developed approach within the Kurdish political movement. The Anglo-Iraqi Treaty of 1930 and the granting of independence to Iraq in1932 were followed by a series of disturbances and rebellions. The two largest rebellions were those lead by Sheikh Mahmud in March 1931, and Barzani during 1930-1932.

The second generation adopted a more radical anti-British stance and introduced anti-imperialism into Kurdish political literature. In 1944, the YeketiTekoshin (hereafter Tekoshin) was established and later evolved into the Communist Party of Iraqi Kurdistan, which was popularly known as Shoresh. There were several pillars of Tekoshin ideology that became the legacy of and embraced by many Kurdish political parties. The main legacy of Tekoshin was the adoption of an anti-imperialist discourse. The Tekoshin insisted that one of its main goals was to liberate Kurdistan from imperialism and its reactionary agents (i.e., the Iraqi state and the Kurdish tribal and religious leaders).$^{34}$ In 1945 , the Rizgari Party issued a memorandum stating that Kurdistan had been incorporated into Iraq by force without consulting the Kurds. The Rizgari Party also described the annexation asthe dismemberment, exploitation and humiliation of the Kurds by "hateful imperialism." ${ }^{35}$ It is noteworthy that from the 1940s in the struggle against imperialism, (i.e. the British) was a common goal of most Kurdish parties. Kurdish animosity toward the British resulted in their embracing the socialist camp along with their ideas.

A similar perspective on the British role in forcing Kurds to be part of Iraq was shared by the third generation of Kurdish nationalists. In 1960, the Khabat newspaper, the mouthpiece of the Kurdistan Democratic Party (KDP), published an article written by the Party's general secretary, suggesting that historically the term 'Iraq' had been used to describe a land much smaller than what is known today as Iraq. Khabat further explained that Kurdistan had never been part of Arab land, and the part annexed to Iraq was part of Kurdistan and not Arab land. Khabat also stressed that the term 'Iraq' as a political entity was formed after WWI, by the forcible annexation 
of Southern Kurdistan to Iraq. In 1988, Jalal Talabani, the founder and the leader of the PUK since 1975, stated that Iraq, which included Kurdistan, was an artificial and problematic entity created by 'imperialism'. Talabani also insisted that the Kurds had been forcefully incorporated into Iraq by British imperialist army forces against their rights and own wishes. He also argued that the annexation was a gift to its 'puppet' regime, the Arab rulers of Iraq, for helping the British fulfil their imperialistic goals. ${ }^{36}$ Komalla accused Britain as being an occupier of Kurdistan who attached part of the Kurdish homeland to the country of Iraq ${ }^{37}$ Another important organisation that rejected the legitimacy of the annexation of Kurdistan to Iraq is the Iraqi Kurdistan Front (IKF). The IKF was established in 1987/1988 as an umbrella for all Kurdish political parties, including the PUK and the KDP. ${ }^{38}$ In in its constitution the IKF pointed out that the incorporation of Kurdistan into Iraq was an imperialistic decision that went against the wishes of the Kurdish nation. ${ }^{39}$

The latter generation of Kurdish nationalists also viewed the incorporation of Kurdistan within Iraq as a deed of imperialism by the British. Founded in 1992, the Kurdistan Regional Parliament, then known as the National Assembly of the Kurdistan Region (KNA) or the Parliament of Kurdistan, stated that against Kurdish will and demands, Southern Kurdistan had been attached to Iraq by the use of force ${ }^{40}$ In 2008, a similar interpretation was given in decree no. 2 of the Kurdistan parliament. It insisted that as a result of colonial economic interests and hegemony Southern Kurdistan had been attached to Iraq. ${ }^{41}$ Thus, it is widely believed that to fulfil imperialist interests, aka British interests, Kurdistan was annexed to Iraq and this was done against Kurdish wishes and without considering Kurdish opinion.

\section{AnNEXATION OF KURDistan TO IRAQ is A USURPATION OF THE KURDish Right OF SELF-DETERMinATION}

The common belief among the Kurds is that the Kurdish nation is eligible for, but deprived of, the right to self-determination. From the Kurds perspective, the attachment of Kurdistan to Iraq was imposed upon Kurdistan through an imperialistic process against its will and this meant the usurpation of their right to self-determination. Viewed in this way, many Kurds understood their right to self-determination to be usurped by the British and the League of Nations. Most political parties, personalities and institutions in the last century have described the annexation of Kurdistan to Iraq as a clear violation of the Kurds' right to self-determination. As early as the 1930s, TawfiqWahbi, the authorised representative of many Kurdish organisations and leaders, called for the right toself-determination. ${ }^{42} \mathrm{~A}$ similar view was adopted by the second generation of Kurdish nationalism. For example, in the 1940s the Rizgari Party stated that the awarding of Kurdistan to Iraq ultimately led to the denial of self-determination for the Kurds Kurds. The Rizgari Party demanded full natural rights and a full opportunity for self-determination for the Kurds. ${ }^{43}$ Between 1940 and 1958 Kurdish nationalists unsuccessfully pursued another method which was to communicate with various international bodies and leading statesmen. Jwaideh reviewed 24 letters and Andrews (1982) documented 20 letters, notes and memoranda that were presented by Kurdish nationalists to foreign powers. They found that the Kurds' demands ranged from protection and minority rights to the right to self-determination and full independenceindependence. ${ }^{44}$

The third generation also followed the same norm of their predecessors. For example, the Kurdistan Toilers' League (Komalla) that dominated the Kurdish political scene in the 1980s described the attachment of Kurdistan to Iraq as a usurpation of the Kurds right toself-determination. ${ }^{45}$ In 1988, Talabani, then secretary general of the PUK, held that the process was a clear violation of the Kurds' right to self-determination. ${ }^{46}$ In fact, self-determination has beena constant theme of the PUK since $1985 .{ }^{47}$ The IKFalso stated that the Kurdish question was a direct result of the usurpation of the Kurds' right to self-determination. The IKF emphasised that a lasting and just settlement of the Kurdish question rests on the attainment of the right to self-determination. ${ }^{48}$ The latter generation has also adopted a similar perspective. In 1992, the Kurdistan National Assembly (Parliament) stressed that the Kurds were entitled to practice their right to self-determination but that international interests have prevented them from carrying out this 
right. ${ }^{49}$ The more conservative KDP, that demanded autonomy until 1992, also emphasised the Kurds' right to self-determination. Attaining self-determination has been the main feature article of theParty's program since its $11^{\text {th }}$ conference held in $1993 .{ }^{50}$ Hence, for the majority of Kurdish nationalists, being part of Iraq is equivalent to the usurpation of the right to self-determination.

The denial of the Kurds' right to self-determination cut so deeply that it bred discontent, disorder, and rebellion throughout the years of the last century. On one hand, the solution to the Kurdish question based on their right to self-determination became the theme of prominentKurdish parties. Kurdish historyin Iraq has been characterised by the domination of Kurdish nationalist parties that have put the achievement of self-determination at the top of their agendas. Hence, the Kurdish demand for self-determination has historically been a fundamental principle of Kurdish nationalism and its nationhood project. On the other hand, all successive Iraqi governments have rejected the Kurds' right to self-determination. Consequently, these exclusivist respective visions continue to be an important contributing element to the constant state of conflict between Iraq and Kurdistan.It is probably correct to say that the failure of Kurdish integration into the Iraqi state was due to their unending quest for self-determinationon the one side and Iraq's refusal to recognise such a right on the other.

\section{CONCLUSION}

The collapse of the Ottoman Empire, the establishment of many nation-states, and a Kurdish government following WWIplayed a crucial role in in the revival of the Kurds hope of establishing their independent state. By the end of 1924, however, this hope was undermined by Britain and international communities. The colonial power and the League of Nations reneged on their promises and even compromised Kurds' cultural and linguistic rights.Consequently, the Southern Kurds were both shocked and disappointed by the manner in which British powers destroyed the Kurdish government and attached Southern Kurdistan to Iraq by the use of force.By the second half of the 1920s, Southern Kurds found themselves as a neglected minority in the Arab dominated state of Iraq.

The four successive generations of Kurdish nationalistsrejected the legitimacy of Britain's and the League's decision that resulted in the incorporation of Southern Kurdistan into the newly created Iraqi state. For many Kurds being part of Iraq was an imposition designed only to fulfil the goals and intentions of British colonialism. Viewing events in this light, the Kurds rejected the legitimacy of Iraqi rule in Kurdistan and this hasbecome the main obstacle to Kurdish integration into the Iraqi state.The negative impact of the annexation of Kurdistan to Iraq has been reflected in Kurdish political discourse and literature throughout the last century. Kurdish political discourse was built on the rejection of the legitimacy of the process of annexation of Kurdistan to Iraq and the denial of the legitimacy of Iraqi authority in Kurdistan.Thus, Iraq is viewed as an occupier, Kurdistan is seen as an occupied homeland and Kurdish nationalist movementhas portrayed itself as a liberation movement. Kurds equate the process of incorporation of Southern Kurdistan into Iraq as theusurpation of their right of self-determination. In other words, being part of Iraq is perceived as a loss of their inherent right as a nation. Consequently, attaining such a right has become a common goal and shared vision for most Kurdish political parties as well as individuals.

\section{REFERENCES}

1. In this article the term Southern Kurdistan is used to indicate to what today is known as Iraqi Kurdistan. This is for several reasons. First, the term Kurdistan region does not cover all Kurdish areas of Iraqi Kurdistan. Second, it is used to distinguish this part of Kurdistan from other Kurdish areas of Iran, Syria and Turkey. Third, at the time of the annexation of the Kurdish region to Iraq, the region was popularly known as KurdistaniJenubi (Southern Kurdistan). Even after the creation of Iraq, the term 'Southern Kurdistan' was still commonly used by British officials and scholars at least until the mid-1940s. Finally, the use of the term Southern Kurdistan has dominated Kurdish literature and political discourse, and as this article focuses on the Kurds' perspective on the region, it is more relevant to use the term by which they call their region. 
2. After the annexation of Southern Kurdistan to Iraq, four governorates were created out of the Mosul province, Mosul, Kirkuk, Erbil and Sulaimaniya, and Mosul city became the capital of the Mosul governorate in today's Iraq. Kurds do not consider the city of Mosul a Kurdish city, particularly after the creation of the Duhok Governorate in 1968 that included most Kurdish districts of the Mosul governorate. The Kurds, however, insist that Kirkuk is an integrated part of Southern Kurdistan. They also consider the Sinjar (Shengal) and Shekhan districts of Mosul as part of Southern Kurdistan.

3. For the full text of Woodrow Wilson's 14 Points, see American History, viewed 26/12/2009, < http://www. hbci.com/ tgort/14points.htm>.

4. For the full text of the memorandum see:Sherko, B. (1986),Keshay Kurd: Mezhwinwe u Estay Kurd (Kurdish Question: Old and Present History of the Kurds), Muhammad Hama Baqi (trans.),ShahidJa'farPress: 138150.

5. For the articles of the Treaty of Sèvres, see WWI Document Archive, viewed 11/08/2009, <http://wwilib. byu.edu/index.php/Section_I\%2C_Articles_1_-_260>.

6. Eskander, S. (2000), "Britain's Policy in Southern Kurdistan: The Formation and the Termination of the First Kurdish Government, 1918-1919," British Journal of Middle Eastern Studies 27(2): 139-163: 161.

7. Sluglett, P. (1976), Britain in Iraq: 1914-1932, Ithaca, Press, London: 116: Olson, R. (1987), "The Second Time around: British Policy toward the Kurds (1921-22), " Die Welt des Islams 27(1/3): 91-102: 101; Emin, N. (2000), 'Asr al-Qalam wa al-Muraja'at 1928-1931 (The age of pen and petitions 1928-1931), Suleymaniya, Iraq: Khak Press: 198, 313; Fieldhouse, D. K. (2002), "Introduction: The Background, Iraq 1918-1944," Kurds Arabs and Britain, D. K. Fieldhouse (ed.), London, UK: IB Tauris, pp. 1-58: 34; Eskander 2000: 163.

8. Hilmi,R. (2003), Yadasht (Memoir), Third edition, Sulaimani, Iraq: Dezgay Chap w PakhshiSardam: 83; Jwaideh, W. (2006), The Kurdish National Movement: Its Origins and Development, Syracuse, New York: Syracuse University Press: 180.

9. Bechar, S (2016), YakamHukmdari Sheikh Mahmud la Slemani (The first rule of Sheikh Mahmud in Sulaimani, Kurdistani New, 5/6/2016, Available at: http://www.knwe.org/Direje.aspx?Cor=6\&Besh=Wit ar\&Jimare=43114, (accessed 20-02-2017).

10. Hilmi, R. (2003), Yadasht (Memoir), Third edition, Sulaimaniya, Iraq: Dezgay Chap w PakhshiSardam: 88; Al-Bayati, A. (2005), Sheikh Mahmud al-Hafid wa al-Nifuz al-Britani fiKurdistan al-Iraq hatta 'am 1925 (Sheikh Mahmud al-Hafid and British influence in Iraqi Kurdistan up to 1925), London, UK: Dar al-Hikma: 148-150.

11. Al-Bayati 2005: 164-166.

12. Talabani, J. (1988), Hawla al-Qadhiye al-Kurdiya (About the Kurdish Question), Kurdistan, Ibrahim Ezzo: 24-26; Williams, M. W. (2004), "The British Experience in Iraq from 1914-1926: What Wisdom Can the United States Draw from Its Experience?" Washington, DC: DTIC Document.

13. League of Nations (1925), "Question of the Frontier Between Turkey and Iraq, report submitted to the Council by the Commission instituted by the Council Resolution of September 30th, 1925," Lausanne, Switzerland: League of Nations: 88.

14. Eskander 2000: 158.

15. League of Nations 1925: 88. 
16. Talabany, N. (1999), Iraq's Policy of Ethnic Cleansing: Onslaught to change national/demographic characteristics of the Kirkuk Region, available at: <http://www.kurdipedia.org/files/books/2013/87924. PDF?ver=130286343280814632>, (accessed 11-01-2017); Shields, S. (2004), "Mosul Questions: Economy, Identity, and Annexation," The Creation of Iraq, 1914-1922, Reeva Spector Simon and Eleanor H. Tejirian (eds.), New York: Columbia University Press: pp. 50-61: 55.

17. See Emin 2000: 197-200.

18. Ibid.

19. The Rizgari Party, aka the Kurdish Liberation Party, was founded in 1944 with the goal of establishing an independent Kurdish state. It was the successor of the Hiwa party and one of the main factions that participated in the establishment of the Kurdistan Democratic Party (KDP) in 1946.

20. For full text of the Proclamation of the Kurdish Rizgari Party, see: Andrews, D. (1982). The Lost Peoples of the Middle East: Documents of the Struggle for Survival and Independence of the Kurds, Assyrians, and other Minority Races in the Middle East. Salisbury, North Carolina: Documentary Publications: 42-45.

21. For the full text of the KDP's National Chapter see Andrews, D. (1982), The Lost Peoples of the Middle East: Documents of the Struggle for Survival and Independence of the Kurds, Assyrians, and other Minority Races in the Middle East, Salisbury, North Carolina: Documentary Publications: 66-67).

22. Talabani, J (1970), Kurdistan wa al-Haraka al-Qawmiya al-Kurdiya (Kurdistan and the Kurdish Nationalist Movement), Baghdad: Al-Nur: 210).

23. The Kurdistan Toilers' League (KomallayRanjderani Kurdistan) that popularly known as Komall, was the largest faction within the Patriotic Union of Kurdistan (PUK) until it dissolved in 1992. Nawsherwan Mustafa currently serves as the General Coordinator of the Gorran (Change) movement, the largest opposition party in the Kurdistan Region.

24. Emin 2000: 257.

25. KRG-ME, Kurdistan Regional Government - Ministry of Education, (2008), Mezhwi Nwe w Hawcharkh Poli Dwazdahami Amadayi Wejayi (New and Modern History for Grade Twelve High School - Humanities), Beirut, Lebanon: Al-Mustaqbal Press: 118-122.

26. Ibid: $179-181$.

27. ZhiyanNewspaper 28/8/1930; SerbekhoyiMegazine25/4/1992.

28. SerbekhoyiMegazine25/4/1992; Emin2000: 199.

29. Zhiyan Newspaper 28/8/1930.

30. League of Nations 1932.

31. Talabani 1970: 61; Ali, O. (2003), Dirasat fi al-Hereke al-Taharruriye al-kurdiye al-Ma'asre 1833-1946 (A Study of the Contemporary Kurdish Liberation Movement), Erbil, Iraq: al-Tafsir: 533; Akrawi (2007), "Kurd u DawlatiSerbekhoBepeyBelganameNewdawlatoyakan" (Kurds and the Independent State Based on International Documents), Erbil, Iraq: Mukiryani: 31, 63.

32. See Bois, T. (1966), The Kurds, M.W.M. Welland (trans.), Beirut: Khayats: 152; Sluglett 1976: 183; Ali 2003 : 603-604).

33. See Zhiyan Newspaper 21/7/1930; Emin 2000: 251-315.

34. YeketiTekoshin Magazine1944: 1-3.

American Research Journal of History and Culture

Page 9 
The 1926 Annexation of Southern Kurdistan to Iraq: the Kurdish Narrative

35. For full text of the memerondum see Andrews 1982: 43-45.

36. Talabani 1970: 210; 1988: 25.

37. Komalla Magazine, "OrganiKomallayRanjderani Kurdistan, (The Review of the Kurdistan Toilers League)" (1981): 19; Komalla Magazine, "OrganiKomallayRanjderani Kurdistan, (The Review of the Kurdistan Toilers League)"1983: 3.

38. Following the Kurdish uprising in 1991, the IKF controlled most of Iraqi-Kurdistan. To achieve internal legitimacy, the IKF arranged the first election in Kurdish history on 19 May 1992.

39. IKF, (Iraqi Kurdistan Front), (1988), Mithaqwa al-Nidham al-dakhili li-Jabha al-Kurdistaniya (The charter and program of Iraqi Kurdistan Front), Kurdistan: Publisher unknown.

40. KNA, (Kurdistan National Assembly) (1992), "BriyariRageyandniFidraly" (The decision of declaration of federalism)," available at: <http://perleman.org/files/articles/080108073542.pdf> (accessed 3/6/2016).

41. Waqai' Kurdistan (The Official Gazette of Kurdistan Region), 17/06/2008, Erbil, Iraq.

42. Emin 2000: 287-296.

43. For full text of the Rizgari party's statement see: Andrews 1982: 44-45.

44. Jwaideh, W. (2006), The Kurdish National Movement: Its Origins and Development, Syracuse, New York: Syracuse University Press: 273-275.

45. Talabani, J.(1988), Hawla al-Qadhiye al-Kurdiya (About the Kurdish Question), Ibrahim Ezzo:6-7, Talabani1970: 210.

46. Talabani: 1988:6-7, Talabani1970: 210.

47. PUK, Patriotic Union of Kurdistan (1986). "Haqiqa al-Mwaqif al-Itihad al-watani al-Kurdistani” (Facts about positions of the Patriotic Union of Kurdistan), Shahid Jaf'ar: PUK, Patriotic Union of Kurdistan, (2001). Bername u Peyrewi Nawkhoy Yekei Nishtimani Kurdistan: Pesend Krawi Yekemin Kongrey Gshti 2001 (The Constitution of the Patriotic Union of Kurdistan: Ratified in the Eleventh General Congress 2001). Publisher unknown: 18.

48. IKF1988.

49. KNA 1992.

50. KDP, Kurdistan Democratic Party (1993),Program u Payrewi Nawxoy Parti Democrati Kurdistan (The Constitution of the Kurdistan Democratic Party), Erbil, Iraq: Chapxaney Xebat; KDP, Kurdistan Democratic Party (2004) "Al-Mnhajwal-Nidham al-Dakhili" (The platform and internal system), Available at, <www. kdp6.com> (accessed 4/1/2017); KDP (Kurdistan Democratic Party) (2010), "Constitution \& Bylaws," Available at: <http://www.kdp.se/kdpprogram.pdf > (accessed 18/4/2016).

Citation: Aram Rafaat. "The 1926 Annexation of Southern Kurdistan to Iraq: the Kurdish Narrative". American Research Journal of History and Culture ; V3, I1; pp: 1-10

Copyright (c) 2017 Aram Rafaat. This is an open access article distributed under the Creative Commons Attribution License, which permits unrestricted use, distribution, and reproduction in any medium, provided the original work is properly cited.

American Research Journal of History and Culture

Page 10 